\title{
Pharmacognostical and Phytopharmacological Investigation of Peltophorum pterocarpum (DC) Backer ex. Heyne
}

\author{
Research Article
}

\section{*Payal M. Panchal}

\author{
*Department of Pharmacogonosy, Dharmaj Degree Pharmacy College, \\ Dharmaj 388430 Gujarat, India
}

\begin{abstract}
This paper deals with the detailed Pharmacognostical and Phytopharmacological evaluation of the crude drug Peltophorum pterocarpum (DC) Backer ex. Heyne (Ceasalpineaceae). Morphoanatomy of the Stem bark have been studied with the aim to aid Pharmacognostical and Taxonomic species identification using light and confocal microscopy, WHO recommended physico-chemical determinations and authentic phytochemical procedures. Two compounds were isolated by column chromatography in different fraction of chloroform, ethyl acetate, methanol and water from stem bark powder. These compounds are tannins which are confirmed by chemical test and TLC. Methanol and water extracts of stem bark of Peltophorum pterocarpum (DC) Backer ex. Heyne, (Ceasalpineaceae) gives analgesic and anti-inflammatory activity, evaluated by rat models.
\end{abstract}

Keywords: Peltophorum pterocarpum (DC) Backer ex. Heyne (Ceasalpineaceae), Morphoanatomy, Confocal Microscopy, Column Chromatography, Pharmacognosy

\section{Introduction:}

Peltophorum pterocarpum (DC) Backer ex. Heyne (Ceasalpineaceae) commonly known as Tamrafali is a large, tall, unarmed evergreen tree; Young branches clothed with reddish brown tomentum; Leaves alternate, compound leaves; Leaflets obliquely oblong; Fruit dark brown legume. The plant grows throughout warmer part of India on road sides and garden. The plant is astringent it cures or relieves intestinal disorders. after pain at childbirth, sprains, bruises and swelling etc. Bark used as a lotion of eye trouble, muscular pain and sores. It is also used for gargles and tooth powders and as an antiseptic powder.

\section{Review of literature:}

Isolation and Identification of Rhamnetin, Quarcetin -3- Diglucoside, Rhamnetin -3'Glucoside, Hirsuitidin, Berginin and 3, 3', 4', 7, 8 - Pentahydroxyflavylium Salt from the fresh pod of Peltophorum pterocarpum (DC) Backer ex. Heyne is reported. Bergenin has shown anti-inflammatory activity on the rat paw edema (1).

*Corresponding Author:

\section{Payal Panchal}

Department of Pharmacogonosy

Dharmaj Degree Pharmacy College

Dharmaj - 388430

Gujarat, India

Email: panchal361@yahoo.com

Phone No.: 91-8128994847

\section{Aim and Objective:}

Inspite of the numerous medicinal uses attributed to this plant, Pharmacognosy and phytopharmacological information about specific stem bark of this plant has not been published. Hence, the present investigation is an attempt in this direction and includes morphological and anatomical evaluation, 
determination of physico-chemical constants, the preliminary Phytochemical screening of the methanolic extract of stem bark of Peltophorum pterocarpum (DC) Backer ex. Heyne and its analgesic and anti-inflammatory activity.

\section{Materials and Methods:}

\section{Plant material}

The plant Peltophorum pterocarpum (DC) Backer ex. Heyne (Ceasalpineaceae) was collected in the month of December-January, 2008-2009 from the area around Vallabh Vidyanagar of Gujarat State. The collected plant was authenticated by taxonomist, Prof. and Head of Botany Dept Dr. Reddy., Sardar Patel University, Vallabh Vidyanagar. A voucher specimen with number (PMP-PP-6/30) was deposited in the Department of Pharmacognosy of A.R. College of Pharmacy, Vallabh Vidyanagar.

\section{Chemicals and Instruments}

Compound Microscope, Glass Slide, Cover slip, Watch Glass and other common glassware were the basic apparatus and instruments used for the study. Micrographs were taken using a Leica DMLS microscope attached with Leits MPS 32 Camera, UV Cabinet, and IR. Solvents are uses Petroleum Ether, Toluene, Chloroform, Methanol and Water.

\section{Macroscopy and Microscopy analysis:}

\section{A) For the preparation of transverse section of Stem Bark (2)}

Boiled T.S. of stem bark in test tube with chloral hydrate for several minute until completely clarified and then examined. After clarification put a drop of glycerin solution and mount the slide under microscope in 10x and 45x objective lens. With another clarified piece of stem bark was stained it with phloroglucinol and concentrated $\mathrm{HCl}$ for 2 minutes and mount the slide for lignified tissue identification. Stain another section with dilute iodine solution.

\section{B) For powder preparation of Stem Bark}

The stem barks of Peltophorum pterocarpum (DC) Backer ex. Heyne (Ceasalpineaceae) were dried under shade. The stem barks were powdered by grinding and passed through the sieve number 60. Finally, from this coarse powder, microscopically examination was done. Slides were prepared same as mentioned in above method.

\section{C) Proximate analysis $(3,9)$}

Proximate analysis aids to set up certain standard for dried crude drugs in order to avoid batch-to-batch variation and also to judge their quality. Their studies also give an idea regarding the nature of phytoconstituents present.

Proximate analysis of these crude drug powders was carried out using methods prescribed in the Ayurvedic Pharmacopoeia of India by subjecting them to various determinations like

i) Total ash

ii) Acid-insoluble ash

iii) Water soluble ash 


\section{C.i) Determination of Ash Values}

The quality of a drug can also be determined by the ash left after ignition. There are four different methods which measure the ash.

\section{a) Total Ash}

The method of total ash is designed to determine the amount of material that remains after ignition. Ash can be classified as physiological ash which is derived from the plant tissue itself and non physiological ash which is the residue after ignition of extraneous matter (e.g. sand and soil).

It is usually carried out at low temperatures possibly because alkali chlorides, which are volatile at low temperatures, may be lost. The total ash consists of carbonates, phosphates, silicates and silica.

\section{Procedure}

About 2-4 gm of grounded material was accurately weighed into a previously ignited and tarred crucible (platinum or silica). The material was spread in an even layer in the crucible and ignited by gradually increasing the heat to $500-600{ }^{\circ} \mathrm{C}$ until it was white indicating that it was free from carbon. The crucible was cooled in desiccators and weighed.

The total ash was calculated as the percentage of ash with reference to the air-dried plant material.

\section{b) Acid-insoluble ash}

Acid-insoluble ash is the residue obtained on boiling the total ash with dilute hydrochloric acid and igniting the washed insoluble matter left on the filter. This determination measures the presence of silica, especially sand and siliceous earth.

\section{Procedure}

$25 \mathrm{ml}$ of hydrochloric acid was added to the crucible containing the total ash and covered with a watch glass. It was boiled gently for 5 minutes. The watch glass was rinsed with $5 \mathrm{ml}$ of hot water and the liquid was added to the crucible. The insoluble matter was collected on an ashless filter paper and washed with hot water until the filtrate was neutral. The filter paper containing the insoluble matter was transferred to the crucible, dried on a hot plate and ignited to a constant weight.

The content of acid-insoluble ash was calculated as a percentage of ash with reference to the air-dried plant material.

\section{c) Water-soluble ash}

Water-soluble ash is the difference in weight between the total ash and the residue obtained after boiling the total ash in water.

\section{Procedure}

The total ash obtained, was boiled for 5 minutes with $25 \mathrm{ml}$ of water. The insoluble matter was collected on an ash-less filter paper. It was washed with hot water and ignited for 15 minutes at a temperature not exceeding $450^{\circ} \mathrm{C}$. The total weight of insoluble matter was subtracted from the weight of the ash. This difference in weights represented the watersoluble ash.

The percentage of water-soluble ash was calculated with reference to the air-dried drug.

\section{C.ii) Determination of Extractive Values $(3,9)$}

This method determines the amount of active constituents extracted with different solvents from a given amount of plant drug. The extraction of any drug with a particular 
solvent yields a solution containing different phyto-constituents. The composition of these phyto-constituents in that particular solvent depends on the nature of the drug and solvent used. The use of a single solvent can be the means of providing information on the quality of a particular drug sample.

\section{a) Alcohol-soluble extractive value}

$5 \mathrm{gm}$ of the air-dried drug was coarsely powdered and macerated with $100 \mathrm{ml}$ of the specified strength in a closed flask for $24 \mathrm{hrs,} \mathrm{shaking} \mathrm{frequently} \mathrm{for} \mathrm{the} \mathrm{first} \mathrm{six} \mathrm{hours} \mathrm{and} \mathrm{slowing} \mathrm{to}$ stand for 18 hours. The macerate was filtered rapidly taking precautions against loss of solvent. $25 \mathrm{ml}$ of the filtrate was evaporated to dryness in a tarred flat bottom shallow dish and dried at $105^{\circ} \mathrm{C}$ to constant weight. The weight was recorded.

The percentage of alcohol-soluble extractive was calculated with reference to the air-dried drug.

\section{b) Water-soluble extractive value}

$5 \mathrm{gm}$ of the air-dried drug was coarsely powdered and macerated with $100 \mathrm{ml}$ of distilled water in a closed flask for 24 hrs, shaking frequently for the first six hours and allowing standing for the next 18 hours. The macerate was filtered rapidly, taking precautions against loss of solvent. $25 \mathrm{ml}$ of this filtrate was evaporated to dryness in a tarred flat bottom shallow dish and dried at $105^{\circ} \mathrm{C}$ to constant weight and weighed.

The percentage of water-soluble extractive was calculated with reference to the air-dried drug.

\section{C.iii) Determination loss of moisture content (9)}

Place about 100gm of drug (without preliminary drying) after accurately weighing it in a tarred evaporating dish. After placing the above said amount of the drug in the tarred evaporating dish, dry at $105^{\circ} \mathrm{C}$ for 5 hours, and weigh. Continue the drying and weighing at one hour interval until difference between two successive weighing corresponds to not more than $0.25 \%$.Constant weight is reached when two consecutive weighing after drying for 50 minutes and cooling for 30 minutes in a desiccators, show not more than $0.01 \mathrm{gm}$ difference.

\section{Phytochemical Screening $(10,33)$}

\section{Successive solvent extraction}

The air dried powdered drug $10 \mathrm{gm}$ was extracted by Soxhlet extractor with successively different solvents, in increasing order of polarity:

Petroleum Ether $\left(60-80^{\circ} \mathrm{C}\right) \rightarrow$ Toluene $\rightarrow$ Chloroform $\rightarrow$ Methanol

Finally it was subjected to maceration with water for 24 hours. The completion of extraction was confirmed by evaporating few drops of the extract from thimble on watch glass to observe that no residue remained after evaporation of the solvent. The liquid extracts obtained with different solvent were collected.

After each extraction, the exhausted powder was kept open to evaporate the solvent. After drying it was packed again in Soxhlet and extracted with next solvent. The extracts were concentrated by distillation until thick viscous residue remained in distillation flask. The extracts were evaporated to dryness below $60^{\circ} \mathrm{C}$, dried in desiccators and weighed. The percent $(\mathrm{w} / \mathrm{w})$ of dry extract was calculated with reference to the dry material.

All the extracts of powder with different solvent were subjected to various qualitative tests and chromatographic studies. 


\section{Qualitative chemical examination (11)}

The extracts obtained from powder by successive solvent extraction were subjected to qualitative examination for the following phytoconstituents:

Alkaloids, Glycosides, Carbohydrates, Phytosterols, Fixed oils, Saponins, Phenolic compounds, Tannins and Flavonoids, Proteins and Amino Acids

\section{Test for alkaloids (12)}

Evaporate the aqueous, alcoholic and chloroform extracts separately. To residue, add dilute $\mathrm{HCl}$. Shake well and filter. With filtrate, perform following tests:

(a) Dragendorff's test: To 2-3 ml. filtrates, add few drops Dragendorff's reagent. Orange brown precipitate is not formed.

(b) Mayer's test: 2-3 ml. filtrate with few drops Mayer's reagent, precipitate not formed.

(c) Hager's test: 2-3 ml. filtrate with few drops Hager's reagent. Yellow precipitate not formed.

(d) Wagner's test: $2-3 \mathrm{ml}$. filtrate with few drops Wagner's reagent. Reddish brown precipitate not formed.

\section{Test for Flavonoids (13)}

(a) Shinoda Test (14)

1-5 $\mathrm{mg}$ of dried extract was extracted with $10 \mathrm{ml}$ of ethanol $(95 \% \mathrm{v} / \mathrm{v})$ for $15 \mathrm{~min}$ on a boiling water bath and filtered. To the filtrate was added a small piece of magnesium ribbon and 3 to 4 drops of concentrated sulphuric acid. Formation of pink color was not observed.

\section{(b) Fluroscence Test (15)}

1-2 mg of dry extract was extracted with $15 \mathrm{ml}$ methanol for $2 \mathrm{~min}$. on a boiling water bath, filtered while hot and evaporated to dryness. To the residue $0.3 \mathrm{ml}$ boric acid solution $(3 \% \mathrm{w} / \mathrm{v})$ and $1 \mathrm{ml}$ oxalic acid solution $(10 \% \mathrm{w} / \mathrm{v})$ were added. The mixture was evaporated to dryness and the residue was dissolved in $10 \mathrm{ml}$ ether. The ether layer do not showed greenish fluorescence under U.V.

\section{Tests for Saponin $(16,17)$}

\section{(a) Froth Test}

$0.1 \mathrm{~g}$ of powder was vigorously shaken with $5 \mathrm{ml}$ of distilled water in a test tube for $30 \mathrm{sec}$ and was left undisturbed for $20 \mathrm{~min}$. Persistent froth was not observed.

\section{Test for carbohydrate (18)}

\section{(a) Molisch's test}

To 2-3 ml. aqueous extract, add few drops of alpha-naphthol solution in alcohol shake and add con. Sulphuric Acid from sides of the test tube, Violet ring was not formed at the junction of two liquids. 


\section{(b) Fehling's test}

Mix $1 \mathrm{ml}$ Fehling A and $1 \mathrm{ml}$ Fehling B solutions, boil for $1 \mathrm{~min}$. Add equal volume of test solution. Heat it on boiling water bath for 5-10 mins. First yellow and then brick red precipitates were not observed.

\section{(c) Benedict's test}

Mix equal volume of Benedict's reagent and test solution in test tube. Heat in boiling water bath for $5 \mathrm{~min}$. Solution does not appear green, yellow or red.

\section{(d) Barfoed's test}

Mix equal volume of Barfoed's reagent and test solution. Heat for 1-2 min. in boiling waterbath and cool. Red ppt was not observed.

\section{(e) Test for Gums}

Hydrolyse test solution using dilute HCl. Perform Fehling's or Benedict's test. Red color was not developed.

(f) Test for Mucilage

$>\quad$ Powdered drug material did not showed red color with ruthenium red.

$>\quad$ Powdered drug do not swell in water or aqueous $\mathrm{KOH}$.

Tests for sterols and Triterpenoids $(19,20)$

\section{(a) Libermann Burchard Test}

Mix $2 \mathrm{ml}$ extract with chloroform. Add 1-2 ml. acetic anhydride and 2 drops of sulphuric acid from the side of test tube. Red color was not observed.

\section{(b) Salkowski Reaction Test}

To the $1 \mathrm{ml}$ of extract, $2 \mathrm{ml}$ chloroform and $2 \mathrm{ml}$ concentrated $\mathrm{H}_{2} \mathrm{SO}_{4}$ were added and shake well. Chloroform layer does not appeared red and acid layer does not showed greenish yellow fluorescence.

\section{Tests for tannins and phenolic compounds (21)}

\section{(a) Test with $5 \% \mathrm{FeCl}_{3}$}

Small amount of extract was taken. To this a drop of freshly prepared 5\% $\mathrm{fecl}_{3}$ solution was added. Deep bluish black color was observed.

\section{(b) Test with Lead acetate solution}

Small amount of extract was taken. To this a drop of freshly prepared Lead acetate solution was added. White precipitate obtained.

\section{(c) Test with Dil. $\mathrm{KMnO}_{4}$}

Small amount of Dil. $\mathrm{KMnO}_{4}$ was taken to this a drop of extract was added. Discoloration of $\mathrm{KMnO}_{4}$ occurred.

\section{(d) Test with bromine water}

Small amount of bromine water was taken to this a drop of extract was added. Discoloration of bromine water 


\section{Tests for Coumarins $(21,22)$}

\section{(a) With Ammonia}

Take a drop of ammonia on a filter paper; to this add a drop of aqueous extract. Fluorescence was observed.

\section{(b) With Hydroxylamine hydrochloride (24)}

Take ethereal extract; treat it with one drop of saturated alcoholic hydroxylamine hydrochloride and a drop of alcoholic $\mathrm{KOH}$. Heat it, cool and acidified with $0.5 \mathrm{~N}$ hydrochloric acid and add a drop of $1 \% \mathrm{w} / \mathrm{v} \mathrm{FeCl}_{3}$. Violet color was obtained.

\section{Tests for Cardiac glycosides (25)}

(a) Baljet's Test:

A thick section did not showed yellow to orange color with sodium picrate.

(b) Legal's Test:

To aqueous or alcoholic extract, add $1 \mathrm{ml}$. pyridine and $1 \mathrm{ml}$. sodium nitroprusside. Pink to red color did not appear.

\section{(c) Keller-Killani Test}

To $2 \mathrm{ml}$. extract, add glacial acetic acid, one drop 5\% Ferric chloride and conc. Sulphuric acid. Reddish brown Color did not appear at junction of the two liquid layers.

\section{Test for Fats and Oil}

\section{(a) Spot Test}

Filter paper gets permanently stained.

Chromatographic examination of various extracts $(34,35)$ :

The various extracts of drug were subjected to thin layer chromatographic studies on silica gel $-\mathrm{G}$ - as adsorbent and different detecting reagents using reported methods to identify the number and nature of chemical constituents present.

\section{Preparation of TLC plates}

Absorbent used: Silica gel G

Vehicle used for preparation of slurry: Water

Method of preparation: Pour Plate Method

Activation of plate: in oven at $110^{\circ} \mathrm{C}$ for $30 \mathrm{~min}$

Application of samples: by the use of Glass Capillary

Mobile phase: Take required quantity of solvent in measuring cylinder and shake well and utilized for saturation of chamber.

Parameters observed: Color of Spot and $\mathrm{R}_{\mathrm{f}}$ value.

\section{Isolation of Phytoconstituents by Column Chromatography:}

The column of about $60 \mathrm{~cm}$ long with an internal diameter of $3 \mathrm{~cm}$ having capacity for holding 50-100gm absorbent was used. Silica gel (230-400\#) was used for the packing as an absorbent. The column was packed by wet packing. At the bottom of the column, cotton plug was kept and wet slurry was made for packing of the column.

\section{Wet packing}

The silica gel $(100 \mathrm{gm})$ was mixed with chloroform in a beaker and poured in to the column. The stationary phase settled uniformly in the column. After wet packing cotton plug was kept on the stationary phase. Above it filter paper kept. 


\section{Sample introduction into the column}

Methanolic extract $(600 \mathrm{mg})$ were dissolved in minimum volume of chloroform, methanol which was used as eluting agent. The dissolving mixtures of solute were poured on the filter paper in the column. Sand washed with acid was kept on the filter paper. The solvent was allowed to run for some time for getting clear solvent.

\section{Gradient eluting technique}

Here four eluting solvent chloroform, ethyl acetate, methanol and water were used the elution were started with chloroform and later ethyl acetate and then methanol and water was increased gradually.

\section{Thin Layer Chromatography (TLC)}

The fraction 1(58-63) and fraction 2 (129-134) contains single spot was used for the identification of the phyto constituents.

Mobile phase: Chloroform: Ethyl Acetate: Methanol: Acetic Acid (9:8:2:1)

Spraying reagent: Folin \& Ciocalteu's Phenol reagent

\section{Spectroscopic Studies (34)}

The Isolated compounds obtained in the column-chromatography were subjected to Spectroscopic studies.

\section{Ultra Violet Spectroscopy}

UV-VIS-NIR Spectrophotometer

Make: Perkin Elmer, U.S.A.

Model: Lambda 19

Specification: Double beam double Monochromator, Ratio Recording

Lamp: Deuterium (UV), Tungsten-Halogen (VIS/NIR)

Detector: Photomultiplier (UV/VIS), Lead Sulphide Cell (NIR)

Wavelength: $185-3200 \mathrm{~nm}$

Scan speed: 0.3 to $1200 \mathrm{~nm} / \mathrm{min}$

Wavelength Accuracy: $\pm 0.15 \mathrm{~nm}$ for UV/VIS $\pm 0.15 \mathrm{~nm}$ for NIR

Baseline flatness: $\pm 0.001 \mathrm{~A}, 4 \mathrm{~nm}$, slit, Golay Savitzky smooth Q

Ordinate mode: Scan, Time drive, Wavelength, Programme, Concentration

Photometric Accuracy: \pm 0.003 A or \pm 0.08

\section{FTIR Spectroscopy:}

Make: Perkin Elmer, U.S.A.

Model: Spectrum GX-FTIR

Method specification

Sample: Solid, liquid and gas

Operating Range: FIR, MIR \& NIR

Scan Range: $15600 \mathrm{~cm}^{-1}-30 \mathrm{~cm}^{-1}$

Scan time: 20 scan/second

Resolution: $0.15 \mathrm{~cm}^{-1}$

Single Beam/Ratio: Single

Detector: MIRTGS \& FIRTGC

Source NIR: $15000-1200 \mathrm{~cm}^{-1}$

Beam splitter opt KBr: $7800-370 \mathrm{~cm}^{-1}$

Detector MIRTGS: $10000-220 \mathrm{~cm}^{-1}$

Optimum range: $7800-1200 \mathrm{~cm}^{-1}$

Detector FIRTGS: $30-780 \mathrm{~cm}^{-1}$ 
OPD velocity: $0.20 \mathrm{~cm} / \mathrm{s}$

Interferogram direction: Bi-Direction

\section{Pharmacological Activity}

Procurement of animals: Sun Pharma, Tandalja, Vadodara India.

Animals required as per CPCSEA
1. Species
: Mice
2. Age/Weight/Size
: 25-30 grams
3. Gender
: Either sex
4. Number to be used
: 30 mice
5. Number of days each animal was housed
: 2 months

They had access to pelleted food and water ad libitum. The animals were assigned to different groups such as Control, Methanol Extract, Water Extract, Standard and each group having six mice to be treated in experiments.

\section{Analgesic activity of Methanol and Water extract (36):}

\section{A) Method: Tail Flick Method}

Animal : Mice

Drugs : Pentozocin (Ranbaxy)

Dose $\quad: 5 \mathrm{mg} / \mathrm{kg}$ i.p., Prepare stock solution containing $0.5 \mathrm{mg} / \mathrm{ml}$ and inject $0.5 \mathrm{ml} / \mathrm{kg}$ of body weight of mouse.

Equipment: Analgesiometer

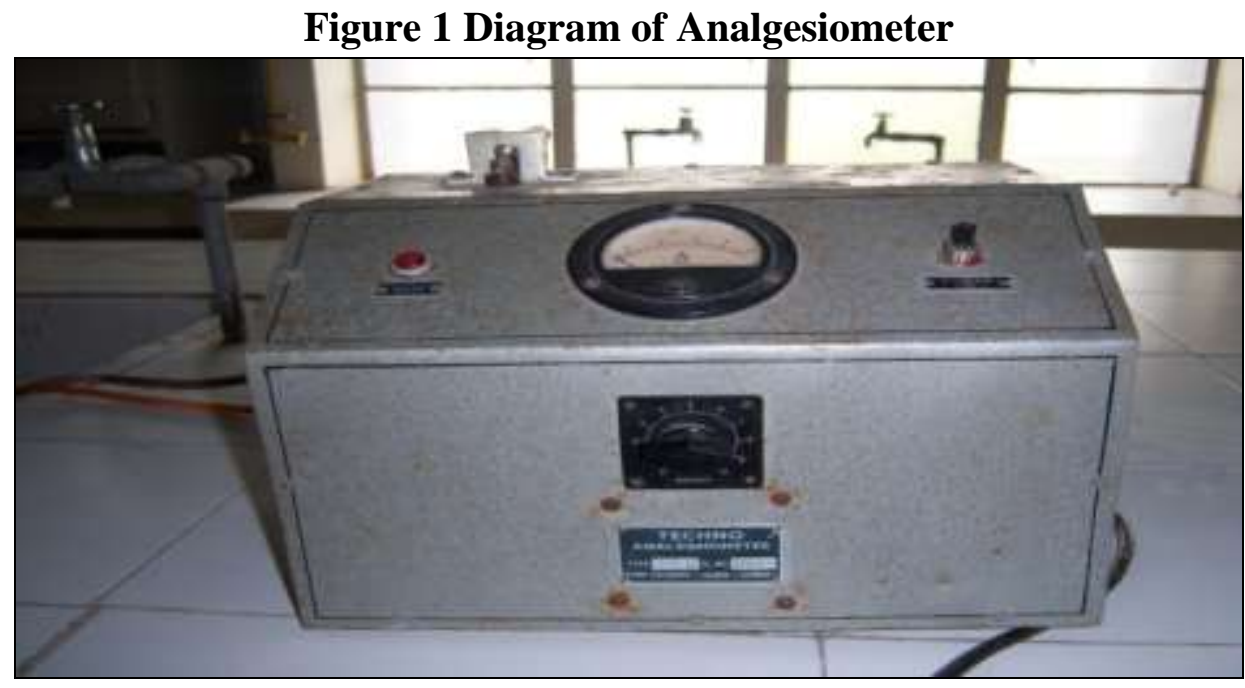

\section{Procedures}

Mice of either sex were weight and numbered. Take the basal reaction time to radiant heat by placing the tip (last $1-2 \mathrm{~cm}$ ) of the tail on the radiant heat source. The tail withdrawal from the heat (flicking response) is taken as the end point. A cutoff period of $10-12 \mathrm{sec}$ is observed to prevent damage to the tail. Inject standard drug and note the reaction time at 5 , 
$15,30 \& 60 \mathrm{~min}$ after the drug. Then percentage increase in reaction time that is index of analgesia at each interval was calculated.

Group-1: Control

Group-2: Standard Drug

Group-3: Test

Different groups are treated with dose $400 \mathrm{mg} / \mathrm{kg}$. Results are compared to control group.

\section{B) Method: Hot Plate Method}

Animal: Mice (20-25gm)

Drugs: Pentozocin

Dose: $5 \mathrm{mg} / \mathrm{kg}$ i.p., prepare a stock solution containing $0.5 \% \mathrm{mg} / \mathrm{ml}$ and inject $1 \mathrm{ml} / 100 \mathrm{gm}$ of body weight of mice.

Equipment: Eddy's Hot Plate method

\section{Procedure:}

Weight and numbered the mice. Take the basal reaction time by observing hind paw linking or jump reaction.(which ever appear first) in animals. When placed on the hot plate maintained at constant temperature $\left(55^{\circ} \mathrm{C}\right)$. Cut off period of $15 \mathrm{sec}$ is observed to avoid damage to the paws. Inject standard to the animals and note the reaction time to the animals on the hot plate at $15,30,60 \& 120 \mathrm{~min}$ after the drug administration. Then percentage increase in reaction time that is index of analgesia at each interval was calculated.

Group-1: Control

Group-2: Standard Drug

Group-3: Test

Different groups are treated with dose of $400 \mathrm{mg} / \mathrm{kg}$. Results are compared to control group.

\section{C) Anti-inflammatory Activity}

The methanol and water extract was evaluated for their anti-inflammatory activity on a carrageenan-induced rat paw edema model. Inflammation was produced in the rats (Male, Wistar, weighing 200-250 g) using $100 \mu \mathrm{L}$ of $1 \%$ carrageenan (wt/vol) in distilled water. This was injected into the plantar surface of the rat's left hind paw. To evaluate the topical anti-inflammatory activity of the formulation, 4 groups of animals $(n=6)$ with carrageenaninduced paw edema were examined. The test drug was given i.p on the paw. The increase in paw volume was measured Plethysmometrically before (time 0) and 1, 3, 6 and 24 hours after carrageenan administration. The difference between the two readings was taken as the volume of the edema and \% inhibition was calculated using the formula mentioned below:

$\%$ Inhibition in Edema $=(\mathrm{A}-\mathrm{B} / \mathrm{A}) * 100(1)$

Where,

$A=$ Mean paw volume in untreated control group

$\mathrm{B}=$ Mean paw volume of treated

Different groups used in the activity are mentioned below:

Group-1: Normal

Group-2: Control 
Group-3: Standard Drug

Group-4: Test Drug

All groups are treated with $0.1 \mathrm{ml}$ of $1 \%$ Carrageenan solution. Results are compared to control group.

\section{Results and Discussion:}

\section{Macroscopic characters of the stem bark (Figure 2):}

The stem bark is $2-6 \mathrm{~mm}$ thick brownish grey color in outer surface and it is rough due to longitudinal cracks and fissures, inner surface dark reddish brown in color, fracture is short in outer surface and fibrous in inner surface.

\section{Microscopic characters:}

Transverse section of stem bark shows periderm, a wide cortex \& secondary phloem. Periderm consists of thin walled and somewhat rectangular 10 to 11 layer of cork cells, 14 to 15 layer of phellogen \& parenchymatous cells of phelloderm containing prisms and rhomboidal calcium oxalate crystals and abundant starch grains. Cortex is interspersed with continuous band of lignified pitted stone cells of different size and shape. Parenchymatous cells of cortex also contain rhomboidal calcium oxalate crystals and a starch grain is present. Continuous band of stone cells are present in phloem region. Medullary rays are bi-triseriate. Simple starch grains are abundantly present in phloem parenchyma.

\section{Powder Characters}

The stem bark powder is reddish brown in color with a characteristic odour. On microscopical examination the powder showed medullary cells with parenchyma cells at right angle, stone cells, rhomboidal calcium oxalate crystals, cork cells, brownish matters and simple starch grains. 


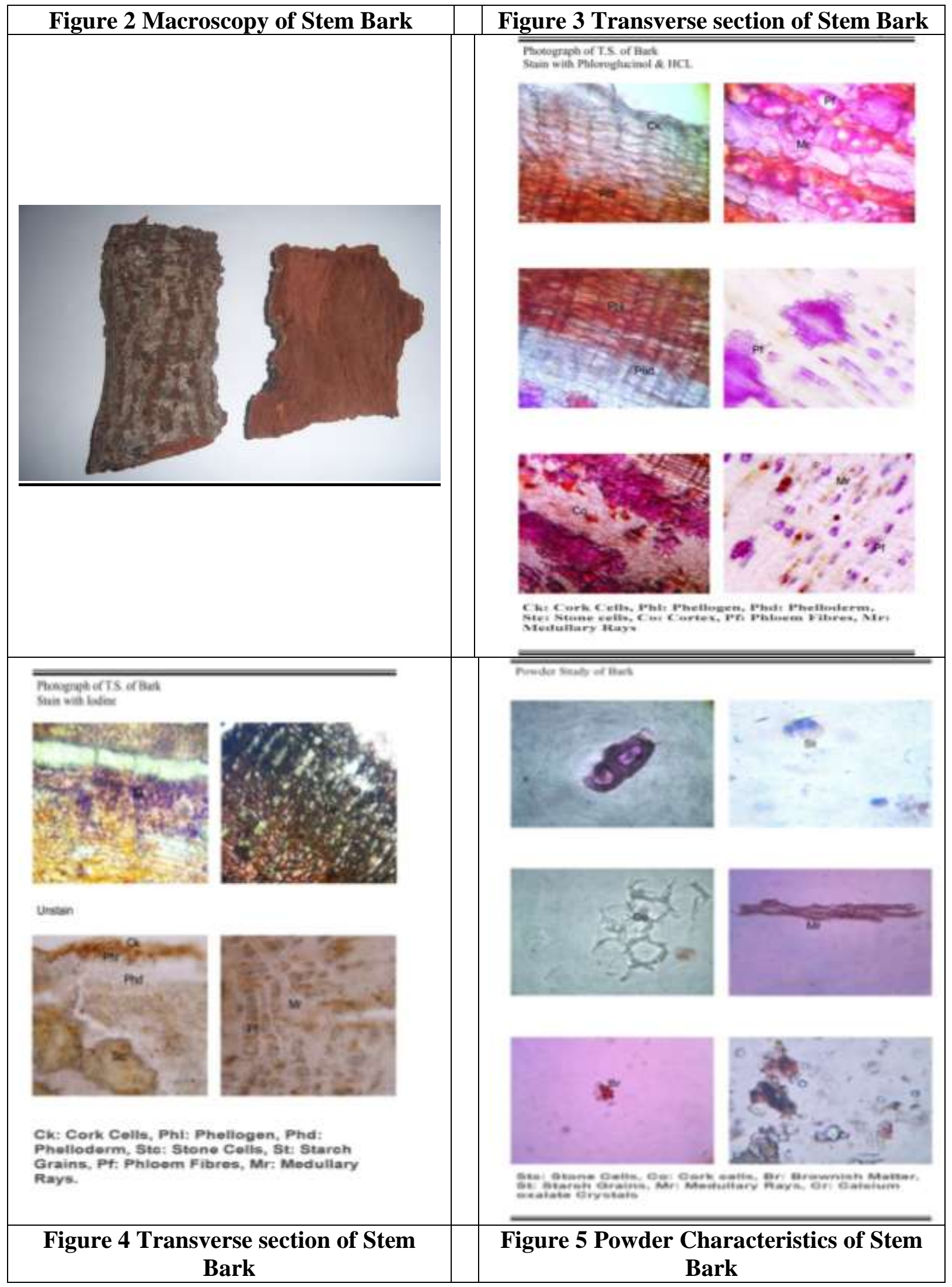


Proximate Analysis:

1. Study of different parameters obtained from proximate analysis of powder of stem bark

\begin{tabular}{|l|l|l|}
\hline Sr. No. & Determination & Percentage w/w \\
\hline 1. & Total Ash & 7.87 \\
\hline 2. & Acid insoluble Ash & 1.25 \\
\hline 3. & Water Soluble Ash & 2.2 \\
\hline 4. & Alcohol Soluble Extractive value & 30 \\
\hline 5. & Water soluble Extractive value & 28 \\
\hline 6. & Moisture content & 42 \\
\hline
\end{tabular}

Table 1 Different Parameters obtained from Proximate Analysis Preliminary Phytochemical screening:

The presence of different chemical constituents in the crude drug can be detected by subjecting them to successive extraction using solvents in the order of increasing polarity. The extract obtained were then dried completely and kept in vacuum desiccators.

They were then subjected to qualitative chemical tests in order to detect the various chemical constituents present in them. The percentage yield of extracts, color, and consistency were determined.

Table 2 Preliminary phytoprofile of Stem Bark of Peltophorum pterocarpum (DC) Baker ex. Heyne (Caesalpiniaceae)

\begin{tabular}{|l|l|l|l|}
\hline Sr.No & Solvent & $\begin{array}{l}\text { Colour and consistency after } \\
\text { drying }\end{array}$ & $\begin{array}{l}\text { Average value (0\% } \\
\text { w/w) }\end{array}$ \\
\hline 1. & Petroleum ether $\left(60-80^{0} \mathrm{C}\right)$ & Yellowish Brown, Solid Mass & 0.93 \\
\hline 2. & Toulene & Pale Yellow, Sticky Mass & 1.64 \\
\hline 3. & Chloroform & Light Cream, Sticky Mass & 0.47 \\
\hline 4. & Methanol & $\begin{array}{l}\text { Reddish Brownish, Solid } \\
\text { Mass }\end{array}$ & 33.82 \\
\hline 5. & Water & Reddish Brown, Solid Mass & 3.29 \\
\hline
\end{tabular}

Table 3 Tests for preliminary Phytochemical screening of stem bark of Peltophorum pterocarpum (DC) Backer ex. Heyne

\begin{tabular}{|c|c|c|c|c|c|c|}
\hline $\begin{array}{l}\text { Sr. } \\
\text { No. }\end{array}$ & $\begin{array}{c}\text { Tests of } \\
\text { phytoconstituents }\end{array}$ & $\begin{array}{c}\text { Petroleum } \\
\text { Ether } \\
\text { Extract }\end{array}$ & $\begin{array}{l}\text { Toluene } \\
\text { Extract }\end{array}$ & $\begin{array}{c}\text { Chloroform } \\
\text { Extract }\end{array}$ & $\begin{array}{c}\text { Methanol } \\
\text { Extract }\end{array}$ & $\begin{array}{c}\text { Water } \\
\text { Extract }\end{array}$ \\
\hline 1. & $\begin{array}{l}\text { Alkaloids } \\
\text { a) Mayer's reagent } \\
\text { b) Dragendorff's } \\
\text { Reagent } \\
\text { c) Hager's reagent } \\
\text { d) Wagner's reagent }\end{array}$ & $\begin{array}{l}* \\
* \\
* \\
*\end{array}$ & $\begin{array}{l}* \\
* \\
* \\
*\end{array}$ & $\begin{array}{l}\text {-ve } \\
\text {-ve } \\
\text {-ve } \\
\text {-ve }\end{array}$ & $\begin{array}{l}\text {-ve } \\
\text {-ve } \\
\text {-ve } \\
\text {-ve }\end{array}$ & $\begin{array}{l}\text {-ve } \\
\text {-ve } \\
\text {-ve } \\
\text {-ve }\end{array}$ \\
\hline 2. & $\begin{array}{l}\text { Test for Flavonoids } \\
\text { a) Shinoda Test }\end{array}$ & $*$ & $*$ & $*$ & -ve & -ve \\
\hline
\end{tabular}




\begin{tabular}{|c|c|c|c|c|c|c|}
\hline & b) Fluorescence Test & $*$ & $*$ & $*$ & -ve & -ve \\
\hline 3. & $\begin{array}{l}\text { Tests for Saponins } \\
\text { a) Froth Test }\end{array}$ & $*$ & $*$ & $*$ & -ve & -ve \\
\hline 4. & $\begin{array}{l}\text { Test for } \\
\text { Carbohydrate } \\
\text { a) Molisch's Test } \\
\text { b) Fehling's Test } \\
\text { c) Barfoed's Test } \\
\text { d) Benedict's Test } \\
\text { e) Test for Gums } \\
\text { f) Test for Mucilage }\end{array}$ & $\begin{array}{l}* \\
* \\
* \\
* \\
* \\
*\end{array}$ & $\begin{array}{l}* \\
* \\
* \\
* \\
* \\
*\end{array}$ & $\begin{array}{l}* \\
* \\
* \\
* \\
* \\
*\end{array}$ & $\begin{array}{l}\text {-ve } \\
\text {-ve } \\
\text {-ve } \\
\text {-ve } \\
\text {-ve } \\
\text {-ve }\end{array}$ & $\begin{array}{l}\text {-ve } \\
\text {-ve } \\
\text {-ve } \\
\text {-ve } \\
\text {-ve } \\
\text {-ve }\end{array}$ \\
\hline 5. & $\begin{array}{l}\text { Test for Sterols and } \\
\text { Triterpenoids } \\
\text { a) Libermann- } \\
\text { Buchard Test } \\
\text { b) Salkowski } \\
\text { reaction }\end{array}$ & $\begin{array}{l}\text {-ve } \\
\text {-ve }\end{array}$ & $*$ & $*$ & $*$ & $*$ \\
\hline 6. & $\begin{array}{l}\text { Test for Tannin \& } \\
\text { Phenolic compound } \\
\text { a) Test with } \mathrm{FeCl}_{3} \\
\text { b) Reaction with Lead } \\
\text { acetate } \\
\text { c) Test with } \mathrm{KMnO}_{4} \\
\text { d) Test with } \mathrm{Br}_{2} \text { in } \\
\text { water }\end{array}$ & $\begin{array}{l}* \\
* \\
*\end{array}$ & $\begin{array}{l}* \\
* \\
*\end{array}$ & $\begin{array}{l}* \\
* \\
*\end{array}$ & $\begin{array}{l}\text { +ve } \\
\text { +ve } \\
+ \text { ve } \\
+ \text { ve }\end{array}$ & $\begin{array}{l}\text { +ve } \\
+\mathrm{ve} \\
+\mathrm{ve} \\
+\mathrm{ve}\end{array}$ \\
\hline 7. & $\begin{array}{l}\text { Tests for Cardiac } \\
\text { Glycoside: } \\
\text { a) Baljet's Test } \\
\text { b) Legal's Test } \\
\text { c) Keller Tillani Test }\end{array}$ & $\begin{array}{l}* \\
* \\
*\end{array}$ & $\begin{array}{l}* \\
* \\
*\end{array}$ & $\begin{array}{l}* \\
* \\
*\end{array}$ & $\begin{array}{l}\text {-ve } \\
\text {-ve } \\
\text {-ve }\end{array}$ & $\begin{array}{l}\text {-ve } \\
\text {-ve } \\
\text {-ve }\end{array}$ \\
\hline 8. & $\begin{array}{l}\text { Tests for } \\
\text { Coumarins: } \\
\text { a) With ammonia } \\
\text { b) With Hydroxyl- } \\
\text { ammine HCL }\end{array}$ & $\begin{array}{l}* \\
*\end{array}$ & $\begin{array}{l}* \\
*\end{array}$ & * & $\begin{array}{l}\text { +ve } \\
+\mathrm{ve}\end{array}$ & $\begin{array}{l}+\mathrm{ve} \\
+\mathrm{ve}\end{array}$ \\
\hline 9. & $\begin{array}{l}\text { Test for Fixed Oil } \\
\text { a) Spot Test }\end{array}$ & +ve & +ve & $*$ & $*$ & $*$ \\
\hline
\end{tabular}

*: Not done -ve: Absent +ve: Present 
Table 4: Thin layer chromatography of the Bark extracts obtained in successive extraction:

\begin{tabular}{|c|c|c|c|c|c|c|c|}
\hline $\begin{array}{c}\text { Phyto- } \\
\text { chemical } \\
\text { Constituen } \\
\text { ts }\end{array}$ & $\begin{array}{l}\text { Solvent } \\
\text { System }\end{array}$ & $\begin{array}{c}\text { Petroleu } \\
\text { m Ether } \\
\text { Extract } \\
\text { (R } \text { and } \\
\text { Color } \\
\text { Spot) }\end{array}$ & $\begin{array}{c}\text { Toluen } \\
\text { e } \\
\text { Extrac } \\
\mathbf{t} \\
\left(\mathbf{R}_{\mathbf{f}}\right. \\
\text { and } \\
\text { Color } \\
\text { Spot })\end{array}$ & $\begin{array}{c}\text { Chlorofor } \\
\text { m Extract } \\
\text { ( } \mathbf{R}_{\mathrm{f}} \text { and } \\
\text { Color } \\
\text { spot })\end{array}$ & $\begin{array}{c}\text { Methan } \\
\text { ol } \\
\text { Extract } \\
\text { (R } \text { and } \\
\text { Color } \\
\text { Spot) }\end{array}$ & $\begin{array}{c}\text { Water } \\
\text { Extract } \\
\text { (R } \mathbf{R}_{\text {f }} \text { and } \\
\text { Color } \\
\text { Spot) }\end{array}$ & $\begin{array}{l}\text { Detectio } \\
\text { n }\end{array}$ \\
\hline \multirow[t]{2}{*}{$\begin{array}{l}\text { Tannins } \\
\text { and } \\
\text { Phenolic } \\
\text { compounds }\end{array}$} & $\begin{array}{l}1 . \\
\text { Chlorofor } \\
\mathrm{m}: \\
\text { Ethyl- } \\
\text { Acetate: } \\
\text { Methanol: } \\
\text { Acetic } \\
\text { Acid } \\
(6: 2: 3: 1)\end{array}$ & - & - & - & $\begin{array}{c}\mathrm{R}_{\mathrm{f}} 0.77 \\
\text { (Blackis } \\
\text { h violet) } \\
\mathrm{R}_{\mathrm{f}} 0.51 \\
\text { (Black) } \\
\mathrm{R}_{\mathrm{f}} 0.4 \\
\text { (Black) }\end{array}$ & $\begin{array}{c}\mathrm{R}_{\mathrm{f}} 0.24 \\
\text { (Black) } \\
\mathrm{R}_{\mathrm{f}} 0.1 \\
\text { (Black) } \\
\mathrm{R}_{\mathrm{f}} 0.5 \\
\text { (Blackis } \\
\text { h violet) }\end{array}$ & $\begin{array}{l}\text { Alcoholi } \\
\text { c } \mathrm{FeCl}_{3} \\
\text { Reagent }\end{array}$ \\
\hline & $\begin{array}{l}\text { Ethyl- } \\
\text { Acetate: } \\
\text { Methanol: } \\
\text { Acetic } \\
\text { Acid } \\
(9: 8: 2: 1)\end{array}$ & 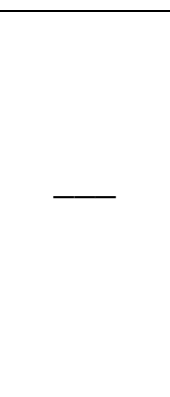 & & - & $\begin{array}{c}\mathrm{R}_{\mathrm{f}} 0.24 \\
\text { (Black) } \\
\mathrm{R}_{\mathrm{f}} 0.6 \\
(\text { Blue) } \\
\mathrm{R}_{\mathrm{f}} 0.4 \\
(\text { Blue) } \\
\mathrm{R}_{\mathrm{f}} 0.26 \\
\text { (Blue) }\end{array}$ & $\begin{array}{c}\mathrm{R}_{\mathrm{f}} 0.4 \\
\text { (Blue) } \\
\mathrm{R}_{\mathrm{f}} 0.36 \\
\text { (Blue) } \\
\mathrm{R}_{\mathrm{f}} 0.17 \\
\text { (Blue) }\end{array}$ & $\begin{array}{l}\text { Folin } \\
\text { and } \\
\text { ciocalteu } \\
\text { 's } \\
\text { Phenolic } \\
\text { Reagent }\end{array}$ \\
\hline
\end{tabular}

$\mathrm{R}_{\mathrm{f}}$ Refractive Value

This compound is catechin type of tannin is confirmed by spectroscopic analysis study (U.V, I.R) and bathochromic shift obtained after addition of alkali.

\section{Isolation of Tannins by Colum Chromatography:}

Two compounds were isolated by column chromatography in different fraction of chloroform, ethyl acetate, methanol and water. These compounds are tannins which are confirmed by chemical test and TLC with Folin and ciocalteu's Phenolic reagent.

Table 2 Isolation of Tannins by Colum Chromatography

\begin{tabular}{|c|c|c|c|}
\hline $\begin{array}{c}\text { Sample } \\
\text { No. }\end{array}$ & Fraction No. & $\mathbf{R}_{\mathbf{f}}$ value & $\begin{array}{c}\text { Color of Spot with Folin } \\
\text { and ciocalteu's Phenolic } \\
\text { reagent }\end{array}$ \\
\hline 1 & $58-63$ & 0.6 & Blue \\
\hline 2 & $129-134$ & 0.4 & Blue \\
\hline
\end{tabular}


(a) Sample 1 (Fraction 58-63)

The data obtained by U. V. Spectroscopy, IR Spectroscopy

The UV Spectra of isolated compound was obtained using Perkin Elmer UV Spectrometer. The Spectra was obtained $200-400 \mathrm{~nm}$ range and showed peak at $275.48 \mathrm{~nm}$. $\lambda \max : 275.48 \mathrm{~nm}$

Table 3 Data for IR Spectrum (Sample- 1)

\begin{tabular}{|c|c|l|}
\hline $\begin{array}{c}\text { Wave numbers } \\
\left(\mathbf{c m}^{-\mathbf{1}}\right)\end{array}$ & $\begin{array}{c}\text { Standard Wave no. range } \\
\left(\mathbf{c m}^{-\mathbf{1}}\right)\end{array}$ & \multicolumn{1}{|c|}{ Characteristics } \\
\hline 2924.13 & $2850-2960$ & C-H Stretching(alkane) \\
\hline 2853.57 & $2850-2960$ & C-H Stretching(alkane) \\
\hline 1741.15 & $1735-1750$ & C=O Stretching (Ester) \\
\hline 1523.89 & $1450-1600$ & C=C Stretching(Aromatic) \\
\hline 1454.34 & $1450-1600$ & C=C Stretching( Aromatic) \\
\hline 1368.83 & $1310-1410$ & C-O Stretching(Phenols) \\
\hline
\end{tabular}

Figure 6 IR Spectra of Sample-1

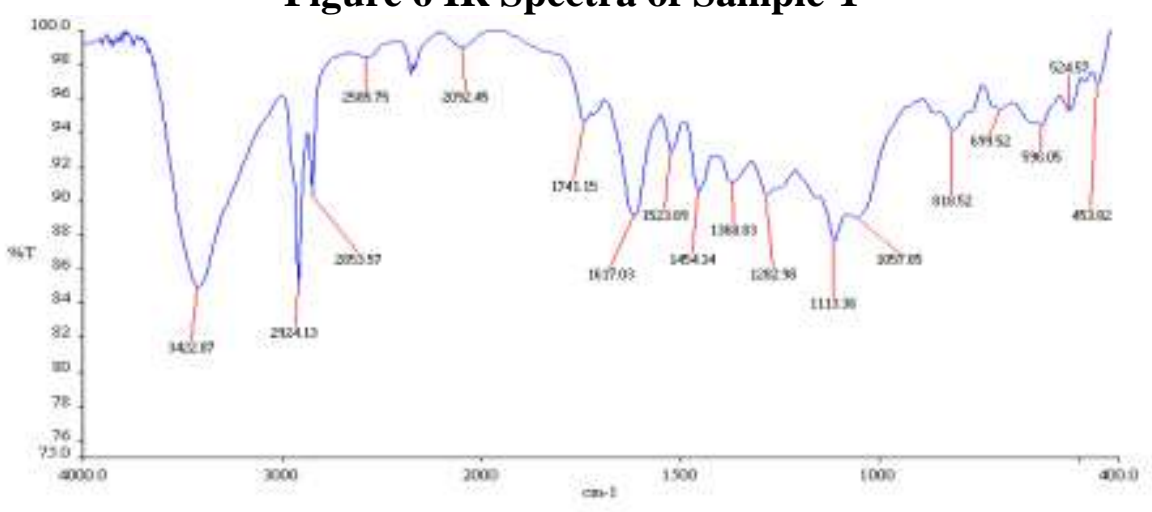

Figure 7 U.V.Spectrum of Isolated compound in Ethanol after addition of Alkali

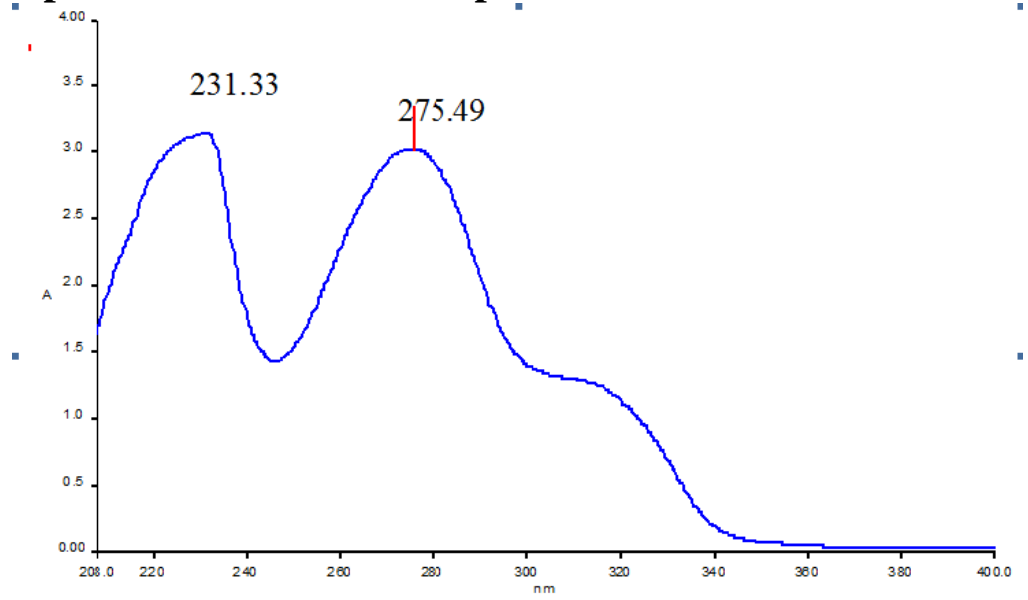

Fraction 1 
(b) Sample 2 (Fraction 129-134):

The data obtained by U. V. Spectroscopy, IR Spectroscopy

The UV Spectra of isolated compound was obtained using Perkin Elmer UV Spectrometer. The Spectra was obtained 200-400 $\mathrm{nm}$ range and showed peak at $281.52 \mathrm{~nm}$. $\lambda \max : 281.52 \mathrm{~nm}$

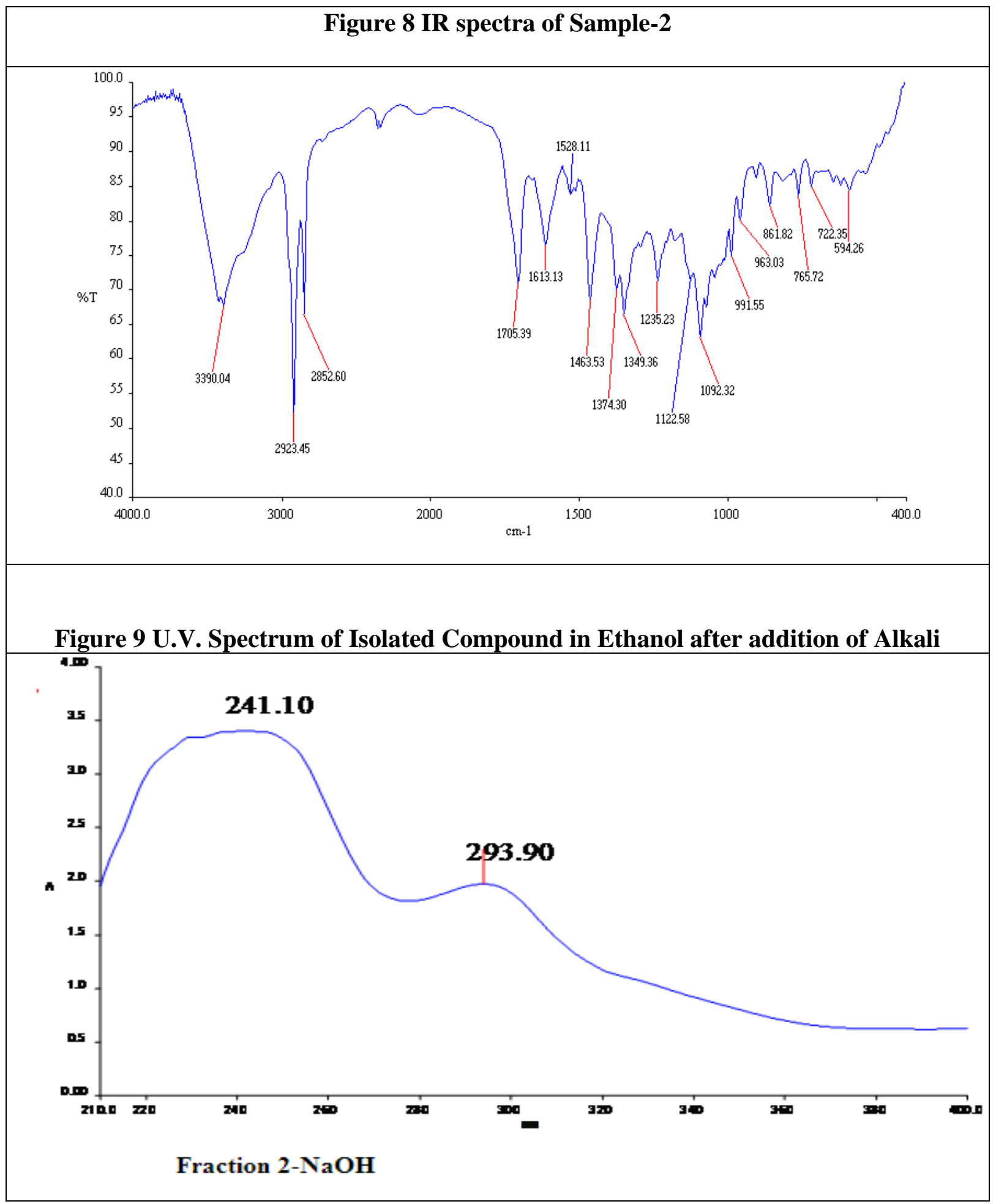


Table 4 Data for IR spectrum (Sample-2)

\begin{tabular}{|l|l|l|}
\hline $\begin{array}{l}\text { Wave numbers } \\
\left(\mathbf{c m}^{-\mathbf{1}}\right)\end{array}$ & $\begin{array}{l}\text { Standard Wave no. } \\
\text { range }\left(\mathbf{c m}^{-\mathbf{1}}\right)\end{array}$ & Characteristics \\
\hline 2923.04 & $2850-2960$ & C-H Stretching (Alkane) \\
\hline 2852.60 & $2850-2960$ & C-H Stretching (Alkane) \\
\hline 1705.39 & $1705-1725$ & $\begin{array}{l}\text { C=O Stretching (Acid) } \\
\text { C=O Stretching (Ketone) }\end{array}$ \\
\hline 1528.11 & $1450-1600$ & C=C Stretching (Aromatic) \\
\hline 1463.5 & $1450-1600$ & C=C Stretching (Aromatic) \\
\hline 1374.30 & $1310-1410$ & C-O Stretching (Phenols) \\
\hline 1349.36 & $1310-1410$ & C=O Stretching (Phenols) \\
\hline
\end{tabular}

\section{Pharmacological Studies:}

1) Analgesic activity

A) Tail Flick Method

Table 5 Effect of Extracts of Stem Bark using Tail flick Method

\begin{tabular}{|l|l|c|c|c|c|c|}
\hline \multicolumn{1}{|c|}{$\begin{array}{c}\text { Animal } \\
\text { group }\end{array}$} & Drug dose & \multirow{2}{*}{$\begin{array}{c}\text { Basal } \\
\text { Reaction } \\
\text { time (sec) }\end{array}$} & \multicolumn{4}{c|}{ Reaction time(sec) } \\
\cline { 4 - 7 } & & $3 \pm 1.5$ & $3 \pm 0.8$ & $3 \pm 1.7$ & $5 \pm 1.5$ & $6 \pm 1.2$ \\
\hline Control & Vehicle & & & & & $\mathbf{3 0 ~ m i n}$ \\
\hline $\begin{array}{l}\text { Methanol } \\
\text { extract }\end{array}$ & $400 \mathrm{mg} / \mathrm{Kg}$ & $4 \pm 2.2$ & $5.83 \pm 0.9$ & $10.83 \pm 2.2$ & $11.29 \pm 1.3$ & $12 \pm 1.7$ \\
\hline Water extract & $400 \mathrm{mg} / \mathrm{Kg}$ & $3 \pm 2.3$ & $4.75 \pm .75$ & $8.35 \pm 2.31$ & $9.42 \pm 1.1$ & $10.55 \pm 1.3$ \\
\hline $\begin{array}{l}\text { Standard } \\
\text { (Pentozocin) }\end{array}$ & $20 \mathrm{mg} / \mathrm{Kg}$ & $3 \pm 0.9$ & $12 \pm .21$ & $12 \pm 1.8$ & $12 \pm 0.9$ & $12 \pm 0.29$ \\
\hline
\end{tabular}

$\mathrm{n}=5$ number of rats in each group done by one way analysis of variance followed by Dunett's test.

$@=\mathrm{P}<0.05$, significant as compare to control.

Graph 1 Comparison of basal reaction time vs time

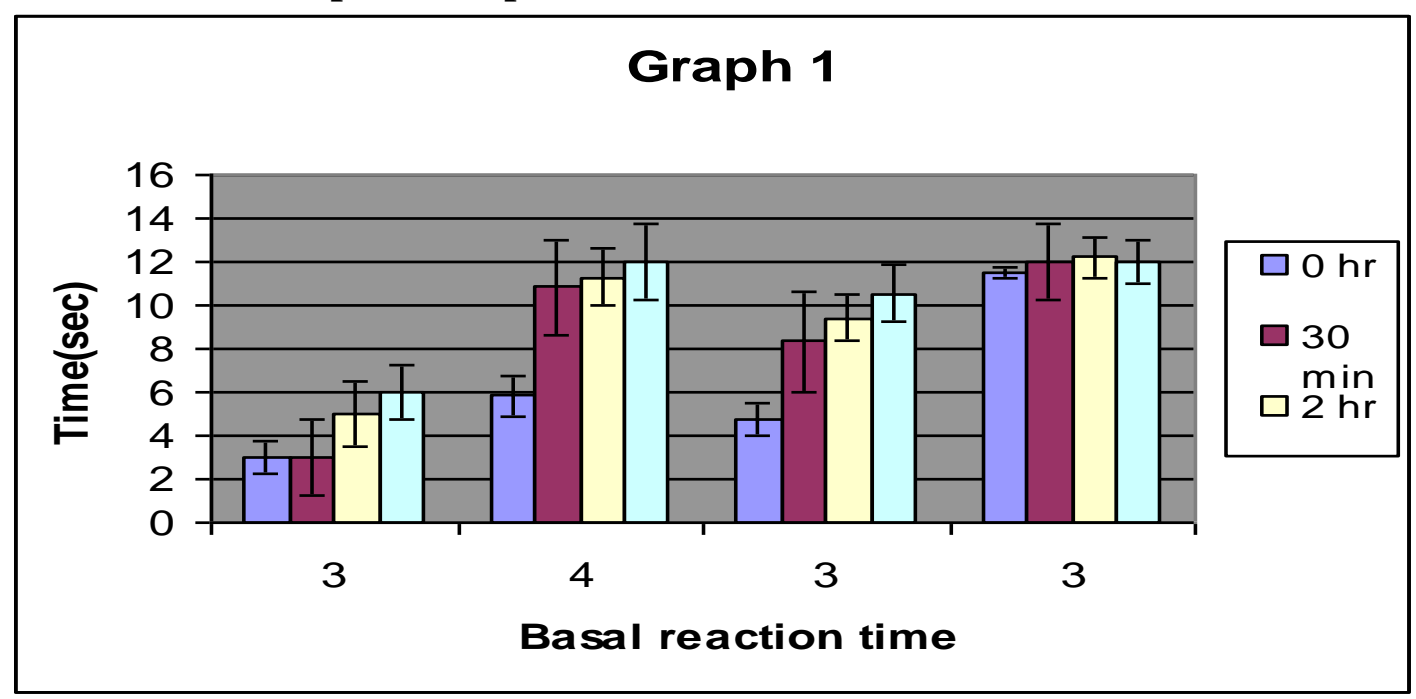


B) Hot Plate Method

Table 6 Effect of Extracts of Stem Bark using Hot Plate Method

\begin{tabular}{|l|c|c|c|c|c|c|}
\hline \multicolumn{1}{|c|}{$\begin{array}{c}\text { Animal } \\
\text { group }\end{array}$} & \multirow{2}{*}{$\begin{array}{c}\text { Drug } \\
\text { dose }\end{array}$} & \multirow{2}{*}{$\begin{array}{c}\text { Basal } \\
\text { Reaction } \\
\text { time (sec) }\end{array}$} & \multicolumn{4}{c|}{ Reaction time(sec) } \\
\cline { 3 - 7 } & & $4.5 \pm 0.4$ & $4.5 \pm 0.31$ & $5 \pm 0.3$ & $4.3 \pm 0.4$ & $4.4 \pm 0.31$ \\
\hline Control & Vehicle & & & & & \\
\hline $\begin{array}{l}\text { Methanol } \\
\text { extract }\end{array}$ & $400 \mathrm{mg} / \mathrm{Kg}$ & $5.0 \pm 0.6$ & $5.75 \pm 0.61$ & $7 \pm 0.6$ & $7.15 \pm 0.64$ & $6.9 \pm 0.5$ \\
\hline $\begin{array}{l}\text { Water } \\
\text { extract }\end{array}$ & $400 \mathrm{mg} / \mathrm{Kg}$ & $5.25 \pm 0.25$ & $5.60 \pm 0.21$ & $6.15 \pm 0.25$ & $6.25 \pm 0.28$ & $6.00 \pm 0.29$ \\
\hline $\begin{array}{l}\text { Standard } \\
\text { (Pentozocin) }\end{array}$ & $20 \mathrm{mg} / \mathrm{Kg}$ & $4.5 \pm 0.7$ & $5.8 \pm 0.6$ & $8.25 \pm 0.6$ & $9.00 \pm 0.7$ & $8.00 \pm 0.2$ \\
\hline
\end{tabular}

$\mathrm{n}=5$ in each group number of rats in each group done by one way analysis of variance followed by Dunett's test.

$@=\mathrm{P}<0.05$, significant as compare to control.

Graph 2 Comparison of Basal reaction time vs. Time

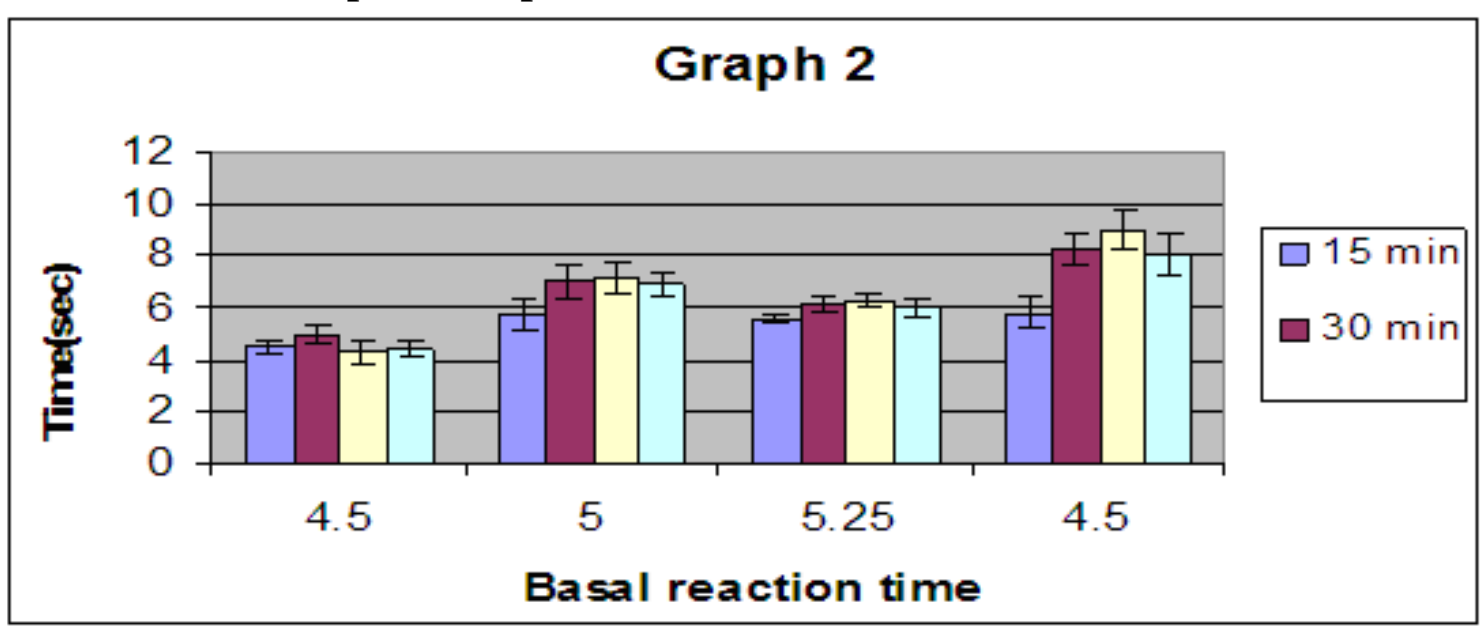

The value of methanol and water extracts of stem bark of Peltophorum pterocarpum (DC) Backer ex. Heyne depicts the analgesic activity. Methanol extract of stem bark gives more analgesic activity as compared to water extract in both the models of analgesic.

2) Anti-inflammatory activity - Increase in paw volume of rats in ml with different groups

Table 7 Effect of Extracts of Stem Bark using Carageenan Rat Paw Edema

\begin{tabular}{|c|c|c|c|c|}
\hline \multirow{2}{*}{ Animal group } & \multicolumn{4}{|c|}{ Increase in paw volume (ml) } \\
\cline { 2 - 5 } & $\mathbf{0 ~ h r}$ & $\mathbf{1 ~ h r}$ & $\mathbf{3 ~ h r}$ & $\mathbf{5 h r}$ \\
\hline Normal & 1.75 & 1.75 & 1.75 & 1.75 \\
\hline Control & 1.85 & 2.25 & 2.45 & 2.61 \\
\hline Methanol extract $(300 \mathrm{mg} / \mathrm{Kg})$ & 1.75 & 1.85 & 1.95 & 2.00 \\
\hline
\end{tabular}




\begin{tabular}{|c|c|c|c|c|}
\hline Water extract $(300 \mathrm{mg} / \mathrm{Kg})$ & 1.71 & 1.79 & 1.88 & 1.96 \\
\hline Standard & 1.90 & 2.10 & 2.25 & 2.9 \\
\hline
\end{tabular}

$\mathrm{n}=6$ in each group

Table $8 \%$ Inhibition of paw edema at in time interval in different groups

\begin{tabular}{|c|c|c|c|c|}
\hline \multirow{2}{*}{ Animal group } & \multicolumn{4}{|c|}{ \% Inhibition } \\
\cline { 2 - 5 } & $\mathbf{0 ~ h r}$ & $\mathbf{1 ~ h r}$ & $\mathbf{3 ~ h r}$ & $\mathbf{5 h r}$ \\
\hline Methanol extract $(300 \mathrm{mg} / \mathrm{Kg})$ & $5.25 \pm 1.5$ & $5.33 \pm 1.7$ & $6.12 \pm 1.2$ & $13.02 \pm 1.8$ \\
\hline Water extract $(300 \mathrm{mg} / \mathrm{Kg})$ & $5.15 \pm 1.07$ & $5.20 \pm 1.67$ & $5.85 \pm 1.3$ & $11.23 \pm 1.6$ \\
\hline Standard & $2.70 \pm 0.9$ & $6.67 \pm 1.6$ & $8.16 \pm 1.5$ & $27.20 \pm 1.4$ \\
& & & & \\
\hline
\end{tabular}

$\mathrm{n}=6$ in each group number of rats in each group done by one way analysis of variance

followed by Dunett's test.

$@=\mathrm{P}<0.05$, significant as compare to control.

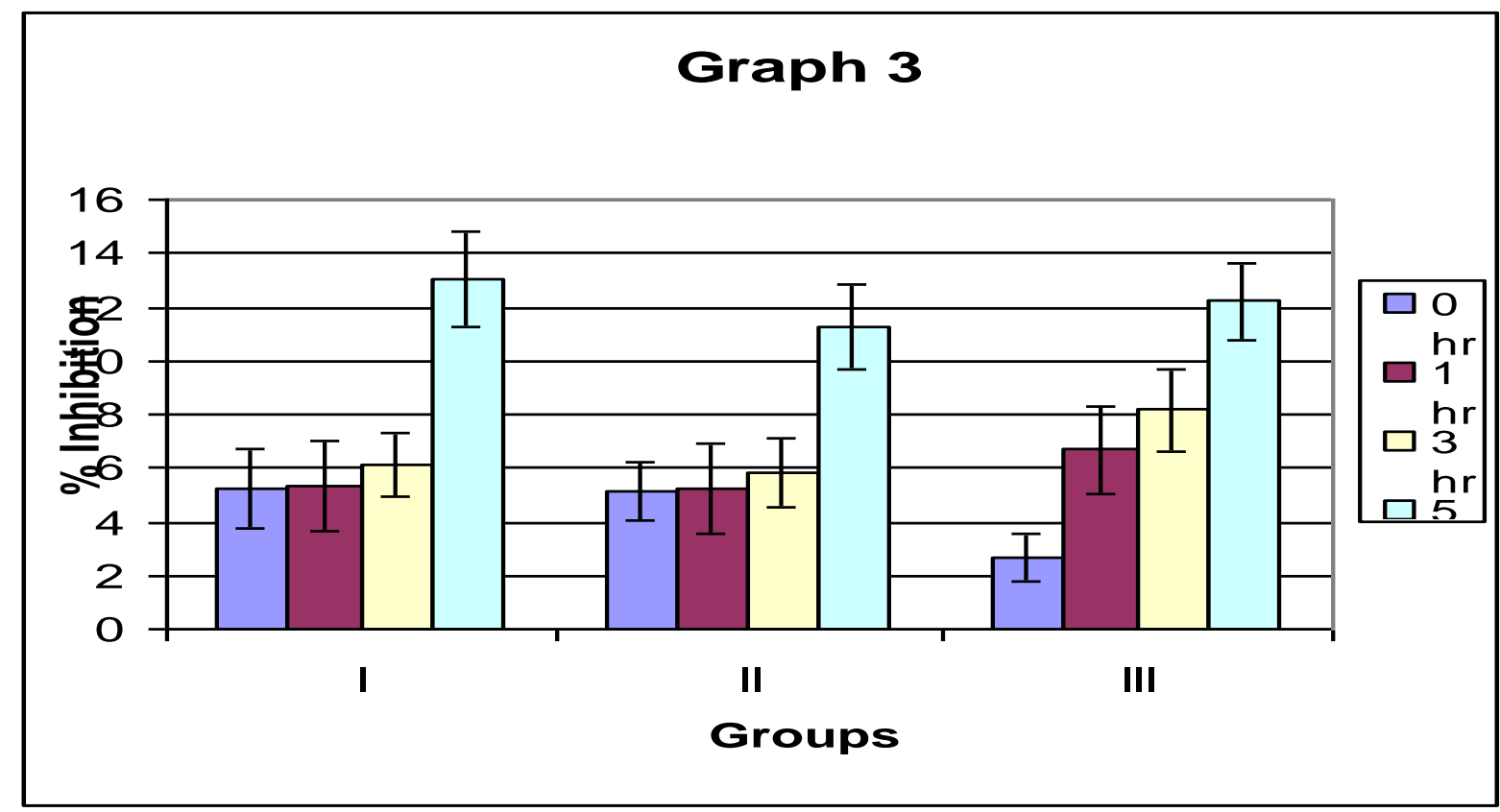

\section{Graph 3 Comparison of \% Inhibitions vs Groups}

\section{Group I: Methanol Extract}

\section{Group II: Water Extract}

\section{Group III: Indomethacin}

The value of methanol and water extracts of stem bark of Peltophorum pterocarpum (DC) Backer ex. Heyne (Ceasalpineaceae) depicts the anti-inflammatory activity. Methanol extract of stem bark gives more anti-inflammatory activity as compared to water extract in Carageenan Rat Paw Edema model of anti-inflammatory. 


\section{Conclusion:}

The present study on Pharmacognostical evaluation of Peltophorum pterocarpum (DC) Backer ex. Heyne (Ceasalpineaceae) will provide useful information for its identification. Macro, Micro and Physicochemical standards discussed here can be considered as the identifying parameters to substantiate and authenticate the drug. The Phytochemical study showed that Tannins and Phenolic compounds are present in the Stem Bark which showed Analgesic and Anti-Inflammatory activity.

\section{References:}

1. Suarnalakshmi G. G, Sulochana N, Anala B . Chemical and Pharmacological studies on Peltophorum Pterocarpum 1985. MAPA-05-2461p.

2. Khandelwal K. R, Textbook of Practical Pharmacognosy Techniques and Experiments, 2ed. New Delhi; Nirali Prakashan; 2000. 13-18p.

3. Khandelwal K. R, Practical Pharmacognosy Techniques and Experiments, 2ed. Pune; Nirali Prakashan; 1998. 146-160p.

4. Anonymous the "Physical constant", Indian Pharmacopoeia, Vol-II, 1996. 53-54p.

5. Mukharji Pulok K, Textbook of Quality Control of Herbal Drugs, 1ed. New Delhi; Business Horizons Pharmaceutical Publishers; 2002. 186-195p.

6. Gupta A. K, Physical Constant: Evaluation of crude drug; Quality Standard of Indian Medicinal Plant; Indian Council of Medical Research; New Delhi; Vol-I; 2003. 236-237p.

7. Dhanoa S. S, Textbook of The Ayurvedic Pharmacopoeia of India, 1ed. Ministry of health and family welfare, department of health, Government of India; 1986. 143p.

8. Anonymous, "British Pharmacopoeia", HMSO, London; 1993. Vol-I; 222p.

9. Anonymous, The Ayurvedic Pharmacopoeia of India, 1ed. Government of India; Ministry of Health and Family welfare, Department of Health, 1986. Vol-I; 143p.

10. Mukharji P. K. Textbook of Quality Control of Herbal Drugs, 1ed. New Delhi; Business Horizons Pharmaceutical Publishers 2002. 708-710p.

11. Kokate C. K. Textbook of Practical Pharmacognosy, 4ed. New Delhi; Vallabh Prakashan, 1994. 148p.

12. Sim S. K. Textbook of Medicinal Plant Alkaloids, University of Toronto Press, 1969. 9p.

13. Geissman A. Textbook of Modern Methods of Plant Analysis, Peach K and Tracy MV 3ed. Heidelberg; Berlin; Springer Verlag, 1955. 471p.

14. Anonymous, Indian Herbal Pharmacopoeia, published by Indian drug manufacture's association, Revised New Edition, Mumbai; 2002. 493-498p.

15. Freudenberg K., Weinger K. Textbook of The chemistry of Flavonoids compounds, Geissman A. ed., Oxford; Pregamon Press 1962. 211p.

16. Simes J. H., Tracey J. G., Webb L. J., Dunstan W. J. An Australian phytochemical survey- 3 Saponins in eastern Australian flowering plants, Australia common wealth scientific Industrial Research organization Bulletin, 1959. 281p.

17. Evans and Trease, Textbook of Pharmacognosy, 15ed; W.B. Saunders Company Ltd., 2002. 193p.

18. Griffin W. J., Owen W. R., Perkin J. E., A Phytochemical survey of eastern Australian plants for Saponins, Planta Medical, 1968, 16; 75-81.

19. Gupta A. K., Tandan N, Sharma M. Textbook of Quality Standard of Indian Medicinal Plants, Indian Council of Medical Research, 3ed. New Delhi; 2005. 79-83p.

20. Wilson J. A., Merill H. B. Textbook of Analysis of Leather and Material, 1ed. New York; The McGraw Hill Book Co. Inc., 1931. 290-293p.

21. Clerk J., Descamps A., Vander M. E. Textbook of Colorimetric method for determining Tannin, Bulletin Assocaition Anciens ed. Brass, University Louvain, 1947. 68-76p. 
22. Robinson T. Textbook of The organic constituents of higher plants, their chemistry sand Inter relationships, Minneapalis; Burgers publishing company, 1964. 64p.

23. Harborne J. B. Textbook of Phytochemical methods, 2ed. Chapan \& Hall Ltd., London; 1973. 42p.

24. Feigle F. Textbook of Identification of Individual Organic Compound In: Spot tests in Organic Analysis, 4ed. London; Elsevier, 1956. 237p.

25. Feigle F, Textbook of Identification of Individual Organic Compound In: Spot tests in Organic Analysis, 4ed. London; Elsevier, 1956; 419-421p.

26. Kokate C. K., Purohit A. P., Gokhale S. B. Textbook of Drugs containing Glycosides In: Pharmacognosy, 12ed. New Delhi; Nirali Prakashan, 1999. 145-155p.

27. Anonymous, WHO Guidelines, 1ed. Delhi; A.I.T.B.S. Publishers and Distributors, 2002. 45- 46p.

28. Khandelwal K. R. Textbook of Practical Pharmacognosy Techniques and Experiments, 9ed. Pune; Nirali Prakashan, 2002. 152p.

29. www.orgchem.colorado.edu/hndbksupport/colchrom/colchrom.html

30. Silverstein R. M., Bassler G. Clayton, Morrill Terence C. Textbook of Spectrometric Identification of Organic Compounds, 5ed. New York, Chichester, Brisbane, Toronto, Singapore; Published by John Wiley \& Sons, INC., 1991. 93-123p.

31. Kulkarni S. K. Handbook of Experimental Pharmacology; 3ed. India; Vallabh Prakashan, 2007. 35-36p.

32. Gupta A. K, Tandon N., Sharma M., Quality Standards of Indian Medicinal Plants, Indian council of medicinal research, Vol-III; New Delhi; 2005. 357p.

33. Harbone J. B., Phytochemical methods, A Guide to Modern Technique of Plant Analysis, 3ed. Springer International, 2005. 154p.

34. www.orgchem.colorado.edu/hndbksupport/colchrom/colchrom.html

35. Silverstein R. M., Bassler G. Clayton, Morrill Terence C. Textbook of Spectrometric Identification of Organic Compounds, 5ed. New York, Chichester, Brisbane, Toronto, Singapore; John Wiley \& Sons, INC., 1991. 93-123p.

36. Kulkarni S. K., Handbook of Experimental Pharmacology, 3rd revised and enlarged ed. India; Vallabh Prakashan, 2007. 35-36p.

\section{Acknowledgement:}

The authors sincerely thank Sardar Patel University, Vallabh Vidya Nagar for providing the necessary facilities to carry out the study. 